\title{
The Risk of Divorce: Style of Communication, Stages of Family Development, and Type of Socioeconomic Status
}

\author{
Yunita Sari, Septiawan Santana Kurnia, and Yuhka Sundaya
}

\begin{abstract}
The aim of this research is to describe the risk of divorce of household in Bandung city, based on three different discipline of science specifically; communication, developmental psychology and economy. This research represents the map of households which are vulnerable to divorce. This study uses 192 households in Bandung. The result shows that the highest risk of divorce is in households which have the following characteristics: (1) Low context communication, families with pre-school children and low socioeconomic status; (2) Low context communication, families with teenagers, low socioeconomic status; (3) High context communication, families with teenagers and low socioeconomic status.
\end{abstract}

Index Terms-Risk of divorce, type of communication, developmental psychology, SES.

\section{INTRODUCTION}

The rise of divorce is one of the most important social developments of recent decades, to mention in Indonesia. Indonesia is the country which the highest divorce rates in Asia Pacific. The rates of divorce is getting higher through the years, which in the last 5 years of 2010-2014, increasing $52 \%$ [1]. This fact is so saddening yet clearly threatening the sustainability of households in Indonesia.

Research about divorce varies very much, but the research about divorce in Indonesia nowadays are only focusing on certain discipline of science and the theories being used are partial. For example, psychology has only focused on dimension of marital interaction, such as conflict management [2]. Meanwhile, in the science of communication, [3] indicates how the symbolic behaviors occur in a divorce conflicts or [4] test the characteristics of interaction in the families which are at the edge of divorce, describes the relationships of member in the family after the divorce, and analyzes the "meta- message" which occurs in the divorce itself. From the discipline science of economy, [5] started with building a theory about social interaction and demand. The proposition explains how individual doesn't have much freedom to choose when the social influence is very strong. For example, the increase of income in household may not influence the amount of children or the tendency to divorce, when the income of one household compares to the other households in one social group doesn't change. Reference [6] sees that a household is not a static

Manuscript received December 11, 2015; revised March 1, 2016.

Y. Sari is with the Faculty of Psychology, Islamic University of Bandung, Indonesia (e-mail: yunitasari.psy@gmail.com).

S. S. Kurnia is with the Faculty of Communication Science, Islamic University of Bandung, Indonesia (e-mail: septiawansantana@gmail.com).

Y. Sundaya is with the Faculty of Economic Science, Islamic University of Bandung, Indonesia (e-mail: yuhkas@yahoo.com). institution. In the last decades, the rates of marriage are decreasing, the rates of divorce are increasing, and the characteristics of the marriage itself are experiencing a change. The approach of economy with households tries to explain those trends with a model which can also explain how and why a family can be formed. He ends with an argument that, "the marriage may happen when the potential benefit of the marriage is quite big".

Unfortunately, the amount of research of interaction from many disciplines of science nowadays is still very little. Whereas, to understand household as a whole, communication, psychological state, and socioeconomic status need to be seen as an integration and become a baseline to determine the action and behavior. Reference [7] shows that divorce is a complex event that can be viewed from multiple perspectives. Reference [8], also said that it's very much needed to use many different perspectives of science to do research about family study.

Basically, divorce is a kind of an action that the husband and wife decide with many considerations. The cause of divorce also varies. Reference [7] said people's specific reasons for divorcing varied with gender, social class, and life course variables. Economic factors have also been found to be related to divorce, the main one is wives' participation in the labor market [9]. Several studies suggest that Social Economic Status correlates with reasons to divorce.

According to the data in Office of Religious Affairs, West Java, Indonesia, divorce happens because of socioeconomic problems and the absence of harmony in the marriage. The data give early information that the decision of divorce occur because of the socioeconomic pressure. The failure of fulfilling the family needs leads them to have an affair and end up their family into a divorce.

It's clear that we need a broader perspective to understand the case of divorce. Divorce, for married couples, is an act of choice, which is driven by a variety of considerations attached. From the point of view of psychology, every couple occupies the diverse stages of psychological development, and certainly with domestic problems is diverse. From an economic standpoint, they occupy different levels of well-being as well as the communication style of the couple. Aspect of psychology, economy, and communication are intertwined, and not partial.

The goal of this research is to formulize the risk factor in divorce from the communication style, stages in the family development, and type of socioeconomic status (SES).

\section{LITERATURE REVIEW AND RESEARCH FRAMEWORK}

\section{A. High and Low Context Communication}

High context of communication is a kind of communication which most part of information are already 
known by other person, and only a few is being shared [10]. In other words, the meaning of information which is being exchanged through the interaction doesn't need words to communicate with. In the high context culture, communication is only focused on how the message is delivered rather than what is said. This kind of communication is very sensitive with non-verbal message.

In high context culture, communication tends to be less open, and it considers that conflict is dangerous in every kind of communication [10]. In society which holds this kind of culture, conflict needs to be treated carefully. Some countries which hold this culture are Indian America, Latin America, Japan, China, African-American, Korean, and Indonesia. [10]. Otherwise, the low context of communication is the kind of communication which the amount of information is quite big to be shared. Or, in the low context communication, verbal message has more information and only a few which can be found in the certain context or member [10].

The example of society with low context communication is American who rely upon what is being said rather than the nonverbal behavior that accompanies the message. The countries which hold this kind of culture are Germany, Switzerland, Scandinavia, and North America [10].

Generally, low context communication is the kind of direct verbal mode, non-verbal immediacy, and sender-oriented values. The sender of the low context communication has a responsibility to deliver the message clearly.

In low context communication, the sender is hoped to build a clarity, so the receiver will decode the message easily. Meanwhile, the high context communication shows the pattern of indirect verbal mode, self-effacing talk, the vagueness of nonverbal, and the sensitivity of the receiver.

Personally, everyone has their own style in communication, not only how they talk but also the topics they talk about. This uniqueness is inherited by someone from one's culture. Reference [11] differentiated the high-context culture with low-context culture which has several important difference in encoding the information. The low context communication specifically has explicit verbal message, direct verbal mode, simple, and honest.

In low culture context, they say what they mean and they mean what they say. If they say, "Yes" it means that they truly accept or agree. For example, the sentence in low context communication is in computer program. Every message has to be specified with certain codes, unless the program may not work. The characteristics of low context communication are fast and easy to change because will not build a group.

Whereas, the high context culture has implicit message and less honesty. The true message is usually hidden under their non-verbal behavior of the sender: tone voice, hands-moving, posture, face expression, eyes, and even in physical context (how one's dressed, the artifact, etc.). The verbal can be different or even an opposite with the non-verbal message. For example, they use short sentence. The characteristics of this communication context are high durability, slow to change, and tend to bind the group that uses it. Furthermore, the people in this high culture context usually more aware to filter new culture rather than people with low context culture.

\section{B. Framework Research}

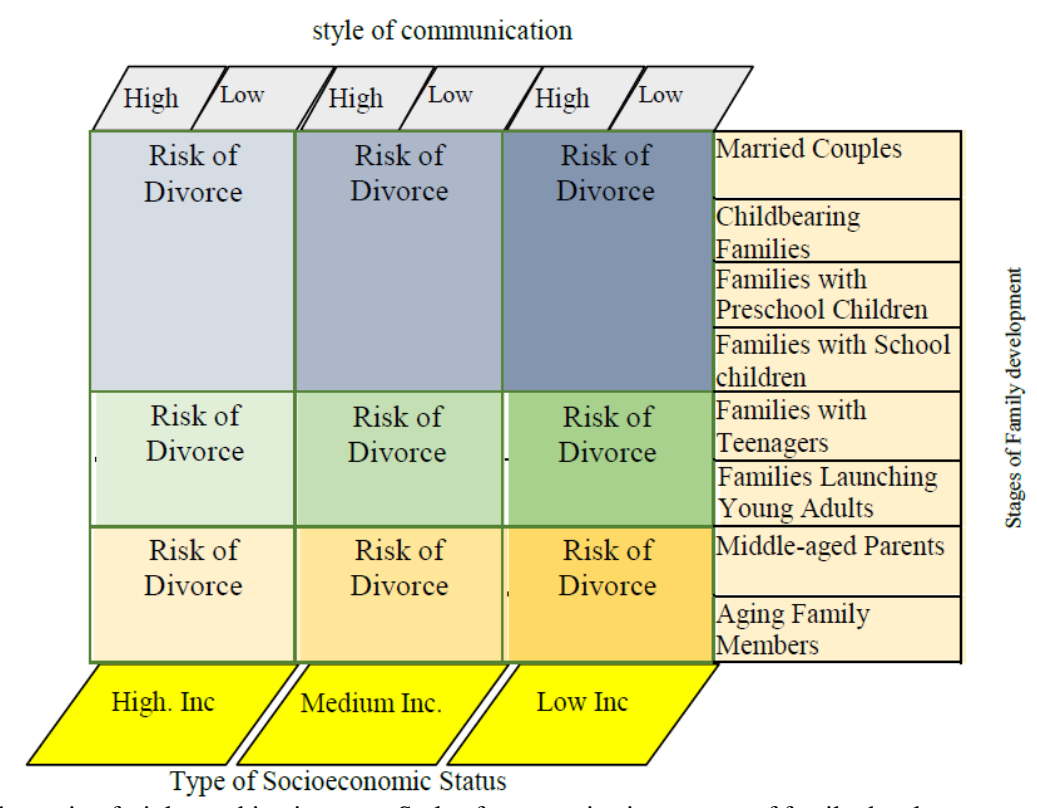

Fig. 1. Household divorce risk matrix of triple combination type: Style of communications stages of family development and type of socioeconomic status.

\section{METHOD}

This research uses descriptive method to gain knowledge about domestic considerations to take the option of divorce or not. Samples are taken randomly from households in
Bandung city due difficulties in obtaining the data of respondents complete address from Office of Religious Affairs. This is because in Indonesia, divorce problem are managed by the office.

This study uses 192 households out of 123 households in 
the city of Bandung. The level of precision obtained is 123 percent.

Information on divorce excavated from two sources, namely household and the Office of Religious Affairs. Researchers presented 36 questions posed to respondents with the basic idea that has been influenced by economic aspects, communication and developmental psychology.

Meanwhile, the questions for the Office of Religious Affairs include the reasons why households decided and not decided to divorce.

The data extracted from respondents are then tabulated to facilitate the production of statistical data into the material to be analyzed multidisciplinary.

\section{RESULT AND DisCUSSION}

Fig. 2 shows the risk of divorce on group communication style, type of socioeconomic status in each of the stages of family development. The magnitude of the risk is obtained through slices of communication styles, stages of family development and type of socioeconomic status among respondents who divorce.

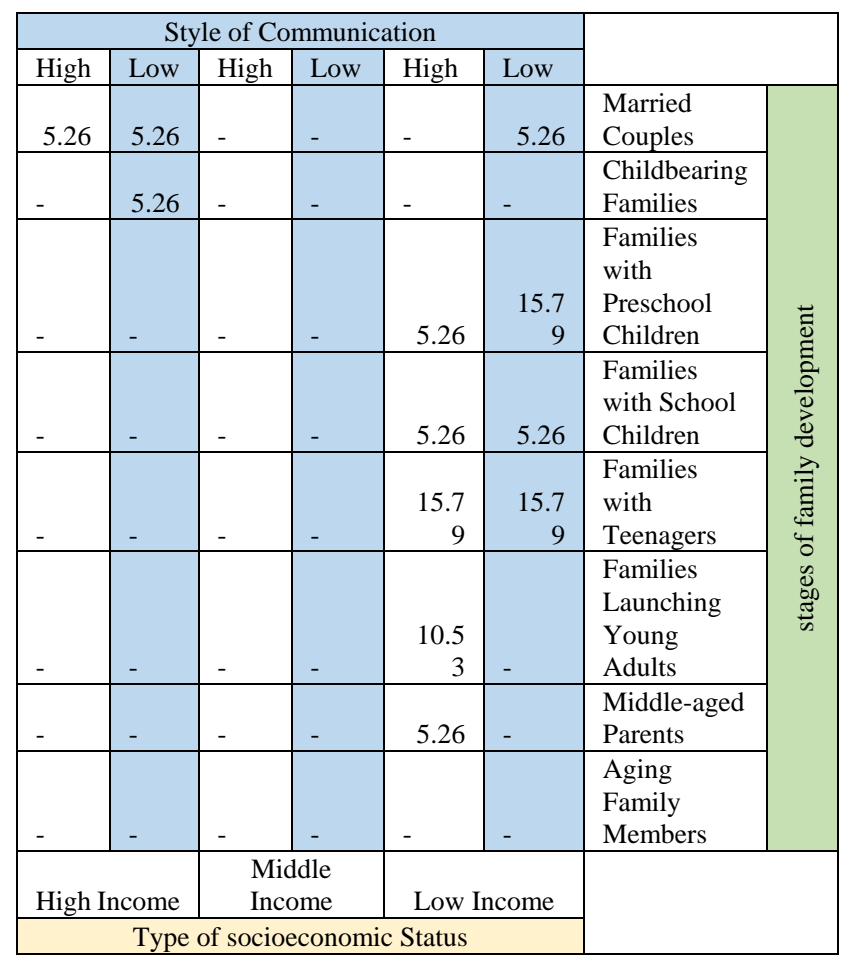

Fig. 2. Divorce Risk percentage of the combination of style of communication, stages of family development and type of socioeconomic status.

Risk of divorce in households in the city of Bandung is in group of high income and low income. As shown in Fig 2, the risk of divorce in households with high income that is equal to 15.79 per cent, and in households with low income by 84.21 percent stakes. Sample in Bandung do not identify a risk of divorce in the middle income group.

The style of communication aspect appeared in this research shows that households with high context communication culture have a greater risk of divorce. The indications are seen in families with low incomes. However, in high-income families, low-context communication style does have a pretty big risk of divorce. Furthermore, the stages of family development appears that households with teenager have a higher risk of divorce.

Slices of communication styles, stages of family development, and the type of socioeconomic status bring empirical information regarding the characteristics of households vulnerable from divorce in the group as follows:

1) Low context communication, stages of families with pre-school children and low socioeconomic status;

2) Low context communication, stages of families with teenagers and low socioeconomic status;

3) High context communication, stages of families with teenagers and low socioeconomic status.

Risk of divorce on the second level has the following characteristics: high context communication, stages of families launching young adults and low socioeconomic status. Risk of divorce estimated at 10.53 per cent of the sample is being studied.

\section{CONCLUSION}

1) The highest risk of divorce is found in low income households and low context communication households, as well as households with teenagers.

2) Low context communication shows that culture of communication in divorce couples indicates a style of western culture communication mixed with Indonesian and Sundanese culture. This situation shows that the divorce couples perceive their partners as strangers from the way they talk as they only concern on their own feeling. They are unable to fully carry out their roles and responsibilities in a marriage like shown in their reluctance and ignorance in seeking for solution to their household problems.

3) The stage of families with teenager tends to experience a crisis both in teenagers and parents who enter different developmental phase.

4) The low income contributes to the cause of divorce households in Bandung. Low income causes problems in fulfilling the household needs while most households have expectations of having a better life. As a result, then, the households decide to divorce.

\section{REFERENCES}

[1] Kompasiana. (December 31, 2015). Catatan Akhir 2015: Perceraian masih terus meningkat. [Online]. Available: http://www.kompasiana.com/pakcah/catatan-akhir-2015-perceraian-m asih-terus-meningkat_56833835c2afbdec04d9e0ee

[2] J. M. Gottman, What Predicts Divorce? Hillsdale, NJ: Lawrence Erlbaum, 1994.

[3] Hopper, Family Communication, New York: McGraw Hill, 1973.

[4] J. Lewis, J. Wallerstein, and L. J. Reitz, The Communication of Older Adults, New York: McGraw Hill, 2004.

[5] G. S. Becker and K. Murphy, Social Economics : Market Behavior in a Social Environment, 1st ed. United States of America: The Belknap Press of Harvard University Press, 2000.

[6] B. A. Stevenson, "Marriage and divorce: Changes and their driving forces," Journal of Economic Perspectives, vol. 21, pp. 27-52, 2007.

[7] Amato, "Divorced adults," in J. W. Santrock, A Topical Approach to Life Span Development, ed. New York: McGraw-Hill, 2012, pp. 454-455.

[8] E. M. Duvall, Marriage and Family Development, USA: J. B. Lippincott Company Philadelphia, 1977, pp. 148-149. 
[9] J. Ermisch, "Divorce: Economic antecendents and aftermath," in $\mathrm{H}$. Joshi, Ed. The Changing Population of Britain, Oxford: Blackwell, 1989.

[10] S. Porter and McDaniel, Culture and Communication, New York: McGraw-Hill, 2010, pp. 257-258.

[11] E. T. Hall, High and Low Context Communication, USA: J. B. Lippincott Company Philadelphia, 1973.

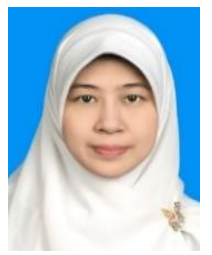

Yunita Sari is a psychologist who was born in Palembang, on June 24, in 1981. She got her bachelor degree in majoring psychology program from Islamic University of Bandung, Indonesia in 2004. In the same year, she continued her study magister professional study psychology majoring in clinical child psychology at Padjadjaran University, Bandung, Indonesia. She finally got the master degree in 2007.

Now, she is actived as a lecturer in Islamic University of Bandung, Faculty of Psychology. She also became a psychologist and consultant in psychology bureau. Her research mainly focuses on family and human development, marital communication and close relationship, education for children and adolescents.

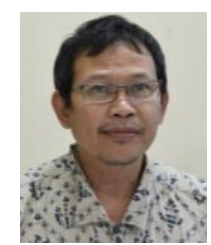

Septiawan Santana Kurnia was born in Purwakarta, on September 6, in 1964. He is a doctorate in communication sciences from the University of Padjadjaran in 2013. There are five books that have been published; Ngomong Like a Writing, Journalism Contemporary, Feature Writing, Investigative Journalism, Literature and Journalism. Since 1997, he is actived as a lecturer in Faculty of Communication Science in Islamic University of Bandung, Indonesia.

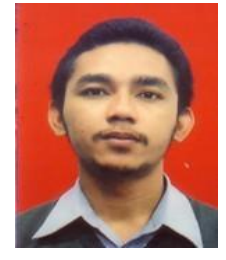

Yuhka Sundaya was born in Ciamis, in 1976. He got his bachelor degree in majoring economic science from Islamic University of Bandung, Indonesia in 1999. He continued his study to pursue his master degree in Bogor Agricultural University. Now, he is actived as a lecturer in Faculty of Economic Science in Islamic University of Bandung. The study area of research is in the field of resource and environmental economics. 